\title{
IMPROVING SERVICE PERFORMANCE FOR AN INTERNATIONAL CONTAINER SHIPPING COMPANY USING INDEX APPROACH:A METHOD AND APPLICATIONS
}

\author{
Kee-Kuo Chen \\ Department of Marketing and Logistics Management, Yu Da University, Miaoli, Taiwan, R.O.C. \\ Jaw-Shen Wang \\ Global Management Group, Yang Ming Marine Transport Corp., Keelung, Taiwan, R.O.C, jswang@yml.com.tw \\ Ching-W Chu \\ Department of Shipping and Transportation Management, National Taiwan Ocean University, Keelung, Taiwan, R.O.C \\ nce. Two measur Chiu Chiu \\ Department of Shipping and Transportation Management, National Taiwan Ocean University, Keelung, Taiwan, R.O.C
}

Follow this and additional works at: https://jmstt.ntou.edu.tw/journal

Part of the Business Commons

\section{Recommended Citation}

Chen, Kee-Kuo; Wang, Jaw-Shen; Chu, Ching-W; and Chiu, nce. Two measur Chiu (2010) "IMPROVING SERVICE PERFORMANCE FOR AN INTERNATIONAL CONTAINER SHIPPING COMPANY USING INDEX APPROACH:A METHOD AND APPLICATIONS," Journal of Marine Science and Technology. Vol. 18: Iss. 5, Article 18.

DOI: $10.51400 / 2709-6998.1932$

Available at: https://jmstt.ntou.edu.tw/journal/vol18/iss5/18

This Research Article is brought to you for free and open access by Journal of Marine Science and Technology. It has been accepted for inclusion in Journal of Marine Science and Technology by an authorized editor of Journal of Marine Science and Technology. 
IMPROVING SERVICE PERFORMANCE FOR AN INTERNATIONAL CONTAINER SHIPPING COMPANY USING INDEX APPROACH:A METHOD AND APPLICATIONS

Acknowledgements

This work was supported by the National Science Council of Taiwan under grant NSC 97-2410-H-019 $-017$.

This research article is available in Journal of Marine Science and Technology: https://jmstt.ntou.edu.tw/journal/ 


\title{
IMPROVING SERVICE PERFORMANCE FOR AN INTERNATIONAL CONTAINER SHIPPING COMPANY USING INDEX APPROACH: A METHOD AND APPLICATIONS
}

\author{
Kee-Kuo Chen*, Jaw-Shen Wang**, Ching-Wu Chu***, and Rong-Her Chiu***
}

Key words: importance-performance analysis, index, partial least squares, information.

\begin{abstract}
The purpose of this study is to provide an alternative approach in importance-performance analysis (IPA) for improving service performance. Two measures, service performance index (SPI) and service improvement score (SIS), will be developed and included in the proposed approach which attempts to utilize both information directly reported by the respondents and indirectly estimated from model estimation as much as possible in IPA. For illustrating the proposed approach, the service performance improvement decision of an international container shipping company is studied. Results indicate that this company only deliveries $75 \%$ service quality desired by the customers, and that the service ability of the front-line employees of this company should be the first priority needed to be improved. The differences between the proposed model and the methods in the extant literature will provide managers and researchers further insights for the study of IPA.
\end{abstract}

\section{INTRODUCTION}

Improving service performance by identifying the attributes with poor performance is the purpose of importanceperformance analysis (IPA) devised by Martilla and James [47]. Many methods which attempted to improve their original work have been proposed in all respects, particularly, in the respect of the methods for determining the relative importance of service attributes. The methods for determining the relative importance of service attributes can be broadly classified into two

Paper submitted: 07/17/09; revised: 09/02/09; accepted: 12/15/09. Author for correspondence: Jaw-Shen Wang (e-mail: jswang@yml.com.tw).

*Department of Marketing and Logistics Management, Yu Da University, Miaoli, Taiwan, R.O.C.

**Global Management Group, Yang Ming Marine Transport Corp., Keelung, Taiwan, R.O.C.

***Department of Shipping and Transportation Management, National Taiwan Ocean University, Keelung, Taiwan, R.O.C. approaches. One approach estimates the attributes' relative importance using the data directly surveyed from respondents; the other uses the coefficients estimated by some statistical models to be the relative importance of service attributes indirectly such as the method of regression analysis. The efficacies of the two approaches reported in the literature are mixed due to a fact that only one kind of information, direct or indirect, was employed by the methods in the extant literature. The purpose of this study is to propose an alternative approach in which both direct and indirect information will be included to IPA. The proposed approach develops a service performance index (SPI) in a way that the attributes included in SPI are determined by a service performance model built according to the knowledge of marketing theories, and then the relative importance of the relevant attributes are determined by the data directly surveyed from respondents. A service improvement score (SIS) is also devised for ranking the improvement priorities for the attributes included in SPI. For illustrating the proposed approach, the service performance improvement decision of an international container shipping company is studied.

Indexes have a long and rich tradition in social science research. Partial least squares (PLS) is a robust statistical method which is capable of mitigating the problems of multicollinearity and skewed service measurements; those are the critical issues in the studies of IPA. SPI and SIS are devised to contain both direct and indirect information for the use of service performance improvement. The differences between the proposed model and the previous methods are (1) SPI provides a numerical descriptive measure for the service performance rather than a visual judgment on an IP matrix, and (2) SIS can assess the improvement priorities for each attributes explicitly.

Another feature of this paper is that, instead of using service quality (SQ) or satisfaction (SAT) as the performance in the previous studies of IPA, the service performance used in the paper refers to overall performance achieved by the firms; that includes overall service quality (OSQ), service value (SV), satisfaction (SAT) and customer behavior intentions (CBI). This feature makes the SPI exclude some important attributes perceived by customers but irrelevant to the firm's overall service performance. This paper pays attention to the aspect 
of information utilization as much as possible. To the best knowledge of the authors, the methodology of this paper is unique in IPA. The authors believe that the proposed approach will provide managers and researchers further insights for the study of IPA.

The rest of the paper is organized as follows. Section II briefly reviews the methods of determining the relative importance of attributes in IPA. Section III introduces the proposed method including the descriptions of the assumptions and procedures, and the definition of SPI and SIS. Section IV presents the methodology of the empirical study which includes the description of the sample, domain of content for service attributes of the studied company, as well as the empirical results and their managerial implications. Finally, the discussions and the directions for future research are concluded.

\section{LITERATURE REVIEW}

Service quality is one of most important drivers of customer satisfaction and, in turn, has critical impact on the firms' profitability [37, 64]. Firms usually monitor service quality perceived by their customers for raising customer satisfaction through identifying and improving important attributes with poor performance. Martilla and James [47] developed IP matrix as shown in Fig. 1.

After Martilla and James, many approaches used to determine the relative importance of the attributes for managerial purposes have been appeared in the literature. Abalo et al. [1], Crompton and Duray [18], Ennew et al. [27], O'Leary and Adams [54], Sambonmatsu et al. [65], Sampson [66] and Yavas and Habib [72] proposed the direct method as the main technique to measure attribute importance. Danaher [22], Deng [23], Dolinsky and Caputo [26], Jacoby et al. [42], Matzler et al. [48, 49], Mittal et al. [52] and Taylor [69] used various indirect methods to measure the importance of attributes. The purposes of these papers using indirect methods attempted to circumvent the problems of direct method [65].

Heeler et al. [39] compared the direct methods including survey from respondents, conjoint analysis [35] and information display board [42]; they concluded that the rankings of attributes' importance obtained from these methods could be very different and that the direct method was the most reliable, but information display board yielded the greatest face validity. Neslin [53] compared the performance of direct method and the analysis of variance and supported the use of analysis of variance due to it's high predictive ability. Jaccard et al. [41] compared six methods: direct survey method, open-ended elicitation, paired comparison, information display board; conjoint analysis and regression analysis. They used structural equation modeling and exploratory factor analysis to examine the convergent validity of these six methods and concluded that strong evidence for convergence was not apparent in the data. Bacon [8] compared the efficacies of measuring the relative importance used by direct survey method and obtained from correlation coefficients or regression coefficients; he found

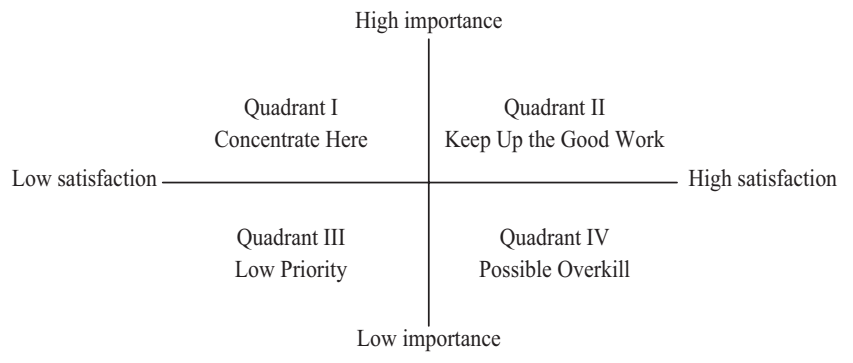

Fig. 1. Importance-performance matrix.

that the direct survey method was better than correlation coefficients or regression.

The above review reveals that, for determining the relative importance of the attributes, two approaches, direct method which obtains information directly from respondents and indirect methods which obtain information from model estimation, have been employed in the literature but the efficacy of the two approaches has not concluded affirmatively. The efficacy comparison through empirical study might be very difficult not only because the methodologies used by the two approaches are unrelated, but also because it would also depend on the quality of sample and model specification. This paper attempts to provide an approach that is able to utilize both information provided by the model which is constructed according to the knowledge of marketing theories and information directly surveyed from respondents to determine the relative importance measures of service attributes and identify the attributes with poor performance.

\section{THE PROPOSED APPROACH}

\section{Assumptions}

The proposed approach is based on the following assumptions of which the first three are summarized from the results of literature review discussed above:

(a) Both direct and indirect methods can provide some but not all of information for determining the relative importance of the attributes.

(b) Statistical models are useful techniques for the examination of which attributes should be considered in IPA [53], but may not estimate the relative importance more precisely than the direct method $[8,39]$.

(c) Methods that use both direct and indirect information adequately are better than that of using only one source of information.

(d) The service performance used in the paper, instead of using service quality (SQ) or satisfaction (SAT) as the performance in the previous studies of IPA, refers to overall performance achieved by the firms which includes overall service quality (OSQ), service value (SV), satisfaction (SAT) and customer behavior intentions (CBI). One believes that the profitability is the most useful measure for a 
firm's performance $[37,64,75]$. However, the profitability is not only affected by product or service attributes but also by the other factors, such as "situational influences" and "monetary constraints" $[2,28]$. Most of the previous IPA studies used SQ or SAT as the performance measures in their paper $[1,23]$. However, CBI is definitely a mediator variable between firm's action and firm's profitability $[37,75]$. Studies have also shown that the much unexplained variations of models using SV or CBI as dependent variables and SQ or SAT as independent variables $[19,45]$ In this paper, evidence shows (refers to Fig. 4 below) that about $30 \%$ unexplained variations expressed in $\mathrm{R}^{2}$ of the latent variable CBI left in the measurement model implies that including these four variables in the service performance are necessary and adequate. On the basis of these results, variables SQ, SV, SAT and CBI and their relationships will be included in the service performance model used by this paper for exposing the firm's performance as thorough as possible.

\section{Procedure}

Under the four assumptions, this paper proposes an alternative approach to improve service performance for firms. The procedure of the proposed method is displayed in Fig. 2 and illustrated in the following subsections. The first two steps in Fig. 2 are generally common in the empirical studies; in particular, it is more important in a study using formative variables to develope indexes which this paper will do than that of reflective variables to develope scale [24, 43]. The third step is to obtain the necessary data directly from the respondents including the empirical distributions of the attributes' importance measures; invalid data also must be examined and deleted. After that, the validity of the measurement model of this paper will be examined using PLS. On the basis of the results from the previous steps, a service performance model which postulates the relationship between the attributes and service performance delivered by service provider is built to select the relevant attributes hierarchically. The selected attributes will be considered as the relevant attributes to the service performance perceived by the customers, and will be employed to construct SPI.

After the relevant attributes are determined by PLS, the relative importance of these attributes will be calculated using the data surveyed from the respondents according to the formula of SPI which will be described below. Combining the relevant attributes and their associated relative importance measures, SPI and SIS will be constructed and the index validity will be examined.

\section{PLS}

Literature has mentioned that some issues will be encountered when SQ is studied. These issues include: (1) the measures of the relative importance and performance of attributes, service quality and satisfaction are skewed [3] and dependent, (2) the multicollinearity problem exists when various attributes

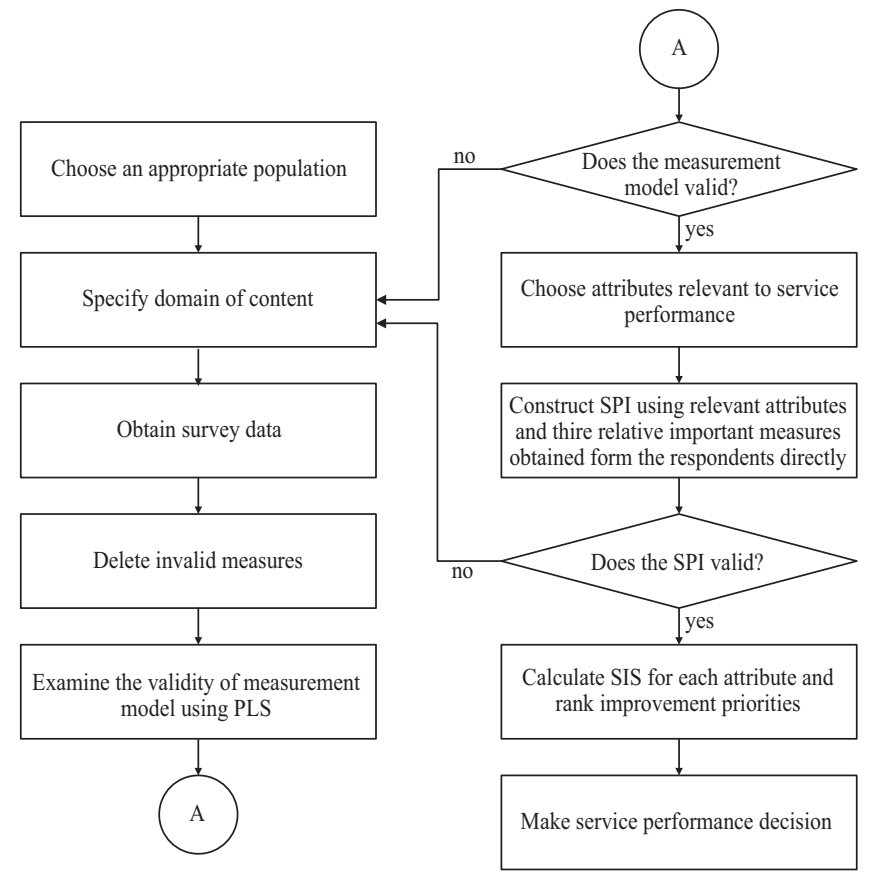

Fig. 2. Index development procedure.

are considered in a model together [8], and (3) the model specification problem may exist in the statistical models [16].

PLS is a robust statistical method having certain advantages: (I) it does not suffer from indeterminacy problems like other causal modeling techniques (e.g. covariance analysis techniques using structural equation modeling or LISREL), (2) it is a nonparametric technique and, therefore, does not assume normality of the data; in fact, the measures of service quality and satisfaction might be skewed [3], (3) it does not require as large of sample sizes as other causal modeling techniques, (4) it often allows researchers to work with more complex models than other causal modeling techniques, (5) it can be used to estimate models that use both formative and reflective indicators [17] and it is more robust to handle the multicollinearity problem than the other competing models such as structural equations modeling [16]. Researches suggest that the characteristics of PLS analysis make it an especially useful tool for index construction $[5,24,30,43]$.

The study employs PLS to verify the validity of measurement model and select the relevant attributes one by one hierarchically [34] for excluding attributes irrelevant to the service performance. All relevant attributes which are tested significantly in hierarchical step will be selected for constructing the SPI. The validity of the developed index will then be assessed by examining how the index is related to other latent variables and also by examining the statistics $R^{2}$ and $Q^{2}$ of the structural model. The $Q^{2}$ statistic, which is a jackknife analogue of $R^{2}$, represents a measure of how well the observed values are reconstructed by the model and its parameters estimates [33, 68]. If $Q^{2}>0$, the model has predictive relevance; conversely, if $Q^{2} \leq 0$, the model lacks predictive 
relevance [17].

\section{The Nature of Indexes}

Index is a valuable managerial tool with many potential applications. It has a long and rich tradition in economical research. Examples of indexes used in marketing research include the American Customer Satisfaction Index (ACSI) [30], the Swedish customer satisfaction barometer [29]. The Deutsche Kundenbarometer [51] and the retailer equity index [5]. A managerial index should be able to assist managers in making decisions. Therefore, an index should possess at least the following appealing properties: (1) the included attributes should have formative property [24]; (2) the contribution of attributes to the index should be presented in their coefficients [11]; (3) an index should include all relevant attributes; and (4) the values of a performance index shall fall into an closed interval.

The above mentioned properties are the necessary conditions for developing a useful index. McColl-Kennedy and Schneider [50] asserted that the criteria that a useful index has to meet were as the following: precision; validity; reliability; predictive power; coverage; simplicity; diagnostics; and comparability. These criteria could not be satisfied if the four mentioned properties were not satisfied. For example, the index would not be valid if it was not developed from the formative perspective, or unable to diagnose the deficiency of service quality provided by a firm if it did not include all relevant variables. The other criteria should depend on the correct definition of the index and the estimation method used to develop it $[3,50]$.

\section{Definition of SPI and SIS}

SPI, a managerial index that can meet the properties abovementioned, is define as follows:

$$
\begin{aligned}
\mathrm{SPI} & =\frac{1}{M} \sum_{j=1}^{K} \frac{i m_{j}}{\sum_{i=1}^{K} i m_{i}} * x_{j} \\
& =\frac{1}{M} \sum_{j=1}^{K} \gamma_{j} x_{j}
\end{aligned}
$$

where $i m_{i}=$ importance score of attribute $i$,

$\gamma_{j}=\frac{i m_{j}}{\sum_{i=1}^{K} i m_{i}}=$ relative importance of attribute $j$

$x_{j}=$ performance score of attribute $\mathrm{j}$, which takes an integer from 1 to $M ; j=1,2, \ldots, K$.

The SPI is normalized by $M$ and is weighted by relative importance perceived by customers delivered by a firm. SPI = $1(100 \%)$ means the service provided by a firm matches the highest level or desired level perceived by its customers [9]. The value of SPI will be between $0(0 \%)$ and $1(100 \%)$; the greater the value of SPI is, the better the service is perceived by the customers. Since

$$
\begin{aligned}
1 & =\sum_{j=1}^{K} \frac{i m_{j}}{\sum_{i=1}^{K} i m_{i}} \\
& =\sum_{j=1}^{K} \frac{i m_{j}}{\sum_{i=1}^{K} i m_{i}}\left[\frac{x_{j}}{M}+\left(1-\frac{x_{j}}{M}\right)\right] \\
& =\mathrm{SPI}+\sum_{j=1}^{K} \frac{i m_{j}}{\sum_{i=1}^{K} i m_{i}}\left(1-\frac{x_{j}}{M}\right),
\end{aligned}
$$

The term $\left(1-\frac{x_{j}}{M}\right)$ can be interpreted as the room for improvement of attribute $j$. Let $\Delta R_{j}^{2}$ be the incremental $\Delta R^{2}$ when attribute $j$ is added in the model for selecting attributes; thus, $\Delta R_{j}^{2}$ can be interpreted as the incremental impact of additional unit performance of attribute $j$ on the service performance perceived by the customers. Combining $\left(1-\frac{x_{j}}{M}\right)$ and $\Delta R_{j}^{2}$, the service improvement scores (SIS) is defined as the following:

$$
\begin{aligned}
\mathrm{SIS} & =\sum_{j=1}^{K}\left[\left(1-\frac{x_{j}}{M}\right)^{2}+\left(\Delta R_{j}^{2}\right)^{2}\right]^{\frac{1}{2}} *\left(\Delta x_{j}\right) \\
& =\sum_{j=1}^{K} \beta_{j}\left(\Delta x_{j}\right)
\end{aligned}
$$

where $\beta_{j}=\left[\left(1-\frac{x_{j}}{M}\right)^{2}+\left(\Delta R_{j}^{2}\right)^{2}\right]^{\frac{1}{2}}$,

$$
\begin{aligned}
\Delta x_{j}= & \text { incremental performance of attribute } j, j=1, \\
& 2, \ldots, K .
\end{aligned}
$$

The coefficient $\beta_{j}$ of $\Delta x_{j}$ in SIS is devised as the distance from the origin to the point $\left(1-\frac{x_{j}}{M}, \Delta R_{j}^{2}\right)$ in the first quadrant of a coordinate system as shown in Fig. 3. In Fig. 3, the horizontal axis denotes $\Delta R_{j}^{2}$ and the vertical axis denotes $\left(1-\frac{x_{j}}{M}\right)$. The pairs $\left[\left(1-\frac{x_{j}}{M}, \Delta R_{j}^{2}\right), j=1,2, \ldots, K\right]$ will be 


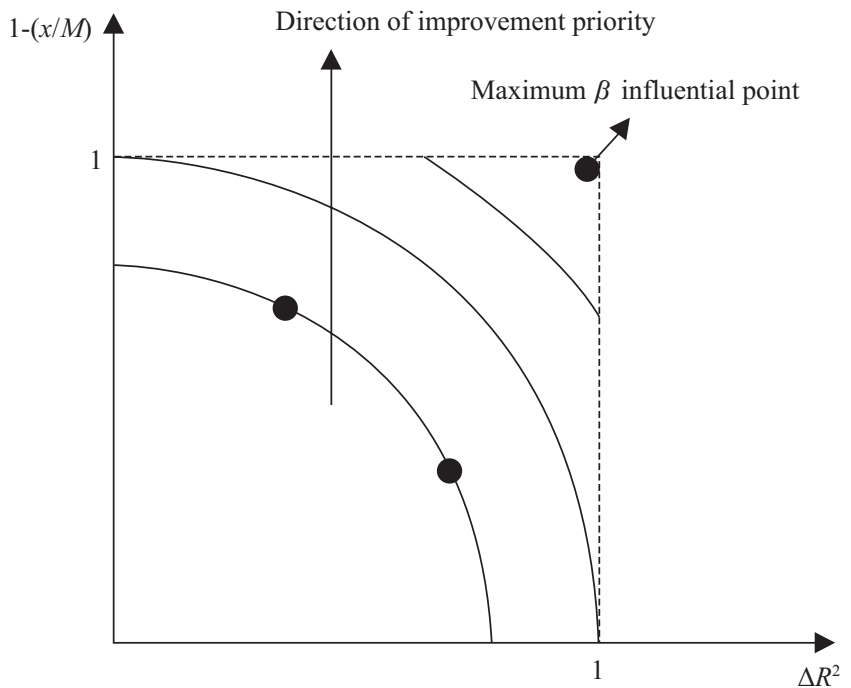

Fig. 3. Improvement priority region.

within and on the boundary of the square of area 1, but excluding two axes. The coefficient of an attribute having maximum $\beta$ is $\sqrt{2}$ which is represented by the point on the northeast vertex of the square. Each circumference of a circle of radius less than $\sqrt{2}$ within the square is an iso-priority curve on which all attributes have the same coefficient $\beta$. Thus, according to the values of $\beta_{j}(j=1,2, \ldots, K)$, the priority of which service activities should be improved could be determined.

It is worth to note that SPI and SIS are devised to contain both direct and indirect information for improving service performance.

\section{THE EMPIRICAL CASE}

To illustrate the proposed method, the service quality improvement decision of an international container shipping company is studied.

\section{The Sample}

A total of 320 questionnaires were sent to the employees who handled shipping affairs of the studied company in 2007. Totally 219 copies of questionnaires were returned, which included 9 copies of incomplete responses. In the end, 210 responses were analyzed which achieved $65.6 \%$ response rate. Among the 210 responses, 110 came from forwarders and another 100 responses were from shippers. Regarding company's total assets, $38 \%$ of the respondents are between US\$ 0.3-1.5 million, while only $2 \%$ have assets exceeding US\$ 156 million.

\section{Measures}

The domain of content for service attributes includes two dimensions: the sacrifice and service quality. Measures were designed to reflect the sacrifice and service quality dimensions of the studied company.
1. Sacrifice. Sacrifice represents the negative effort offered by the service provider, which including such non-pecuniary costs as the time, effort, and risk that customers have to pay in a particular purchase. Some measures of sacrifice have been studied extensively in the literature [19, 25, 45, 73]. In this paper, monetary price was assessed by two direct measures of freight rates for sea or inland transportation. Direct measures of time and mental (effort) that have to be paid by customers in shipping process are employed to measure the nonmonetary cost. These measures which have been adapted by Cronin et al. [19] are adequately modeled as formative indicators in the domain of sacrifice. The risk for customers is measured by the mishandlings and the damage/loss that arises when the cargo is in the delivery process. Thus, the measured variables of sacrifice in this study include six items: ocean freight rate; inland freight rate; negotiation time cost; mental cost; risk of mishandling; and risk of damage/loss. The formative property of these measures has examined by [45]. Since the skewed measurements will affect validity, literature prefers to increase the use of more categories in the scale [4] to remedy the problem. For example, American customer satisfaction index was measured using 10-point Likert scale [3]. In this paper, a nine-point Likert-type response format, ranging from "very low" to "very high" was used for assessing the performance and the importance of all six items.

2. Service quality. For developing formative measures for $\mathrm{SQ}$, with reference to the previous studies [13, 46] and consulting with senior managers of the studied company, the confirmatory process $[36,59]$ was determined to be employed. In addition, the attributes that were considered in the process were examined in accordance with the criteria proposed by [43]. After that, the following steps were implemented subsequently: (1) dividing all businesses into distinguishable 7 categories including export sales (S1), export document (S2), export business (S3), import document (S4), import business (S5), customer complaint \& service (S6), and cargo claim settlement (S7); (2) proposing five constructs from the practical viewpoint of managers: employee ability (Em), service design ability (Sd), operation ability (Op), administrative ability (Ad), and equipment supply ability (Es); and (3) reviewing the activities and the resources (human and capital) involved in each business category and selecting the necessary service items that will affect the five service constructs perceived by customers as the formative attributes. Finally, 30 service attributes were assigned by these consultants. Among them, 21 out of the 30 attributes were included in the study of $\mathrm{Lu}$ [46]. In addition, all attributes mentioned by [13] were included except for two attributes: "freight rates" and "goodwill". "Freight rates" was characterized as an element of the sacrifice construct, and "goodwill" was deleted because it was usually treated as an effect variable of service quality [63]. A nine-point Likert-type scale was used, ranging from "very low" to "very high", to assess the performance and the im- 
portance of service quality attributes.

In the last decade, the validity of the measurements in the studies of service quality (SQ) or satisfaction (SAT) was examined by assessing the relationships between overall service quality (OSQ), service value (SV), satisfaction (SAT) and customer behavior intention (CBI) [19, 44, 45] because these latent variables were the most important factors of service effort delivered by service providers. In this study, except the attributes of sacrifice and service quality, the measurements of OSQ, SV, SAT and CBI which are required to examine the model validity will be measured as follows.

3. Overall service quality. OSQ has been widely studied [7, $14,15,19-21,45,57,58,60-62,70]$ OSQ is the consumer's judgment of an entity's overall excellence or superiority [73]. Ten questions derived from 10 dimensions of SQ [59] that were used by Cronin et al. [19] are used as the measurements of OSQ in this study. A nine-point Likert-type scale, ranging from "very low" to "very high", is employed to assess the measurements of OSQ.

4. Service value. The need for a measure of SV and its potential influence on CBI was first acknowledged by Stokes [67] and Olshavsky [56]. As pointed out by Bolton and Drew [12] and [73], SV is a measure of customers' overall evaluation of a service. Two direct measurements of SV were included in the survey. A nine-point Likert-type scale ranging from "very low" to "very high" was used.

5. Satisfaction. The service management literature argues that SAT is the result of a customer's perception of the value received [6, 30, 38, 55]. Moreover, its potential influence on CBI and customer retention has been recognized by empirical evidence $[19,45]$. Three measurements of SAT was employed for this study, which were the same as the measurements used by [19]. The scoring format for SAT is a nine-point Likert-type scale ranging from "strongly disagree" to "strongly agree".

6. Customer behavioral intention. Theory suggests that increasing customer retention, or decreasing customer defection, is the major key to the ability of a service provider to generate profits [74]. To measure this latent variable, this study employs three items that were similar to the domains assessed in the first four of the five outcomes suggested by [74]. The items are also similar to those reported and used throughout the service marketing literature $[7,19,20]$. A nine-point Likert-type scale, ranging from "very low" to "very high", was used.

7. Control Variables. Finally, each respondent is required to answer the following questions.

(a) Your company is (1) forwarder or (2) shipper.

(b) Your company is (1) domestic or (2) foreigner.

(c) The capital of your company is (1) under 10 million (2) 10-50 million (3) 50-100 million (4) 100 million -1 billion (5) 1 billion-5 billion (6) over 5 billion

(d) The amount you shipped per month is (1) under 10 TEUs (2) 10-100 TEUs (3) 100-500 TEUs (4) 500-1000 TEUs

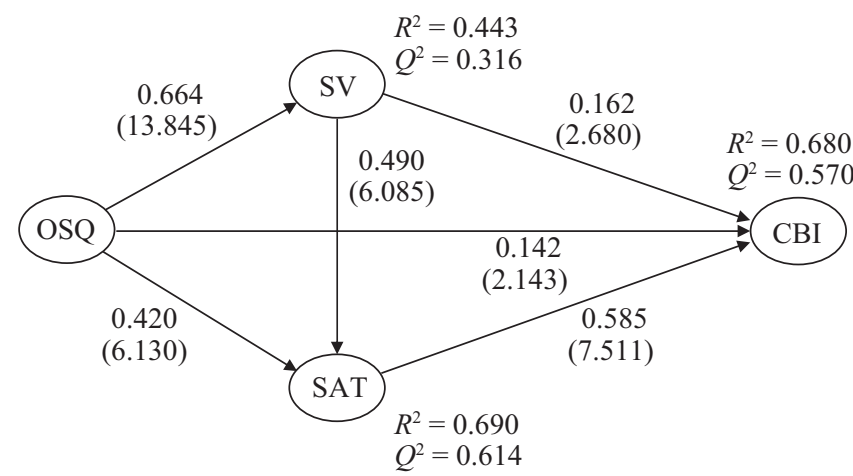

Note: PLS standardized estimates are shown on arrows and their $\mathrm{t}$-values in the parenthesis.

Fig. 4. The structural model.

(5) 1000-2000 TEUs (6) over 2000 TEUs.

(e) The amount you shipped per month in the last three years has (1) greatly decreased (2) slightly decreased (3) remained the same (4) slightly increased (5) greatly increased.

\section{External Validity of Attributes}

To verify the external validity of these 36 attributes ( 6 sacrifice and 30 service items), the mean scores and standard errors of these attributes' performance and importance measurements are presented in the second and third column, respectively, in Table 1. It is apparently that mean scores of the attributes, except "Risk of damage/loss in process", are all significant at a level of $5 \%$.

\section{Validity of Measurement Model}

Because the measurements of OSQ, SV, SAT and CBI lent from the extant literatures such as Cronin et al. [19] and Lages et al. [44] appeared applicable to end-customers rather than business, the validity of the measurements has to be examined. VisualPLS [32] software is employed to examine the validity of the measurement model for the latent variables OSQ, SSV, SAT and CBI. After deleting the item, "Compared to what I had to give up, the overall service of company XXX to satisfy your wants and needs is" which causes SV invalidity, the results of the model using an inner model path weighting scheme [17] show a substantial $R^{2}$ of 0.69 for SAT and of 0.68 for CBI, a moderate level of 0.443 for $\mathrm{SV}$; all values of $Q^{2}$ are positive and larger enough. Besides, all structural paths are found to be significantly examined by the bootstrap re-sampling testing method.

The examination of correlation or internal consistency for the formative model have been argued as inappropriate and illogical [10]. Therefore, the only internal consistency of the reflective part of the research model is assessed by their composite reliability [71] and the average variance extracted (AVE) [31]. As shown in Table 2, the first four rows and columns of this table provide the correlations among the four latent variables 
Table 1. Summary of values of the indexes (SPI).

\begin{tabular}{|c|c|c|c|c|c|c|}
\hline Attributes & $\begin{array}{c}\text { Performance, } \\
\{1\}\end{array}$ & $\begin{array}{c}\text { Importance, } \\
\{2\}\end{array}$ & $\begin{array}{c}\text { Marginal } \\
\text { impact, } \\
\Delta R^{2}\end{array}$ & $\begin{array}{c}\text { Relative } \\
\text { importance, } \\
\gamma_{j}\end{array}$ & $\begin{array}{c}\text { Weighted } \\
\text { Performance, } \\
\gamma_{j}^{*}\{1\} / 9\end{array}$ & $\begin{array}{c}\text { Distance } \\
\text { Coefficient }\end{array}$ \\
\hline Ocean freight rate & $\begin{array}{c}6.319 \\
(1.653) \\
\end{array}$ & $\begin{array}{c}7.980 \\
(1.326) \\
\end{array}$ & .001 & irr. $^{1}$ & irr. & n.a. ${ }^{5}$ \\
\hline Inland freight rate & $\begin{array}{c}6.280 \\
(1.438)\end{array}$ & $\begin{array}{c}7.514 \\
(1.731)\end{array}$ & .001 & irr. & irr. & n.a. \\
\hline Timing cost & $\begin{array}{c}5.314 \\
(1.987) \\
\end{array}$ & $\begin{array}{c}7.080 \\
(1.726) \\
\end{array}$ & .01 & irr. & irr. & n.a. \\
\hline Mental cost & $\begin{array}{c}5.219 \\
(2.028) \\
\end{array}$ & $\begin{array}{r}6.919 \\
(1.731) \\
\end{array}$ & .006 & irr. & irr. & n.a. \\
\hline Risk of mishandling & $\begin{array}{c}4.042 \\
(2.150)\end{array}$ & $\begin{array}{c}7.490 \\
(1.912)\end{array}$ & .002 & irr. & irr. & n.a. \\
\hline Risk of damage/loss in process & $\begin{array}{c}4.947 \\
(2.250)^{4}\end{array}$ & $\begin{array}{c}7.495 \\
(1.957)\end{array}$ & delete $^{4}$ & delete & delete & n.a. \\
\hline Professional knowledge & $\begin{array}{c}3.642 \\
(1.132)\end{array}$ & $\begin{array}{c}7.957 \\
(1.211)\end{array}$ & $.342 *$ & 3.8909 & $\begin{array}{l}3.304 \\
(95.8)^{2}\end{array}$ & $\begin{array}{l}.373 \\
{[8]^{3}}\end{array}$ \\
\hline Problem-solving capability & $\begin{array}{c}7.542 \\
(1.241)\end{array}$ & $\begin{array}{c}8.009 \\
(1.136)\end{array}$ & $.315^{*}$ & 3.9074 & $\begin{array}{l}3.274 \\
(94.2)\end{array}$ & $\begin{array}{l}.354 \\
{[10]}\end{array}$ \\
\hline Active customer care & $\begin{array}{c}7.223 \\
(1.553)\end{array}$ & $\begin{array}{c}7.733 \\
(1.269)\end{array}$ & $.279 *$ & 3.7728 & $\begin{array}{l}3.027 \\
(93.4)\end{array}$ & $\begin{array}{l}.341 \\
{[11]}\end{array}$ \\
\hline Courtesy and patience & $\begin{array}{c}7.300 \\
(1.362) \\
\end{array}$ & $\begin{array}{c}7.833 \\
(1.180) \\
\end{array}$ & $.319^{*}$ & 3.8216 & $\begin{array}{l}3.10 \\
(93.2)\end{array}$ & $\begin{array}{l}.370 \\
{[9]}\end{array}$ \\
\hline $\begin{array}{l}\text { Prompt settlement of customer } \\
\text { complaint }\end{array}$ & $\begin{array}{c}6.961 \\
(1.680) \\
\end{array}$ & $\begin{aligned} 7.880 \\
(1.323) \\
\end{aligned}$ & $.215^{*}$ & 3.8445 & $\begin{array}{l}2.974 \\
(88.3) \\
\end{array}$ & $\begin{array}{l}.312 \\
{[18.5]}\end{array}$ \\
\hline $\begin{array}{l}\text { Communication/interaction with } \\
\text { customers }\end{array}$ & $\begin{array}{c}7.247 \\
(1.381)\end{array}$ & $\begin{array}{c}7.823 \\
(1.234)\end{array}$ & $.389 *$ & 3.8167 & $\begin{array}{l}3.073 \\
(92.6) \\
\end{array}$ & $\begin{array}{l}.435 \\
{[3]}\end{array}$ \\
\hline Availability of cargo space & $\begin{array}{c}6.719 \\
(1.474) \\
\end{array}$ & $\begin{array}{c}7.838 \\
(1.268) \\
\end{array}$ & $.19^{*}$ & 3.824 & $\begin{array}{l}2.855 \\
(85.7) \\
\end{array}$ & $\begin{array}{l}.316 \\
{[15]}\end{array}$ \\
\hline Frequency of sailing & $\begin{array}{c}6.685 \\
(1.456) \\
\end{array}$ & $\begin{array}{c}7.566 \\
(1.293) \\
\end{array}$ & $.195^{*}$ & 3.6913 & $\begin{array}{l}2.741 \\
(88.3) \\
\end{array}$ & $\begin{array}{l}.322 \\
{[12]} \\
\end{array}$ \\
\hline Service coverage of ports & $\begin{array}{c}6.742 \\
(1.477) \\
\end{array}$ & $\begin{array}{c}7.438 \\
(1.400) \\
\end{array}$ & $.16^{*}$ & 3.6289 & $\begin{array}{l}2.718 \\
(90.6)\end{array}$ & $\begin{array}{l}.297 \\
{[21.5]}\end{array}$ \\
\hline On-time cargo loading & $\begin{array}{c}6.985 \\
(1.346) \\
\end{array}$ & $\begin{array}{l}7.828 \\
(.193) \\
\end{array}$ & $.347^{*}$ & 3.8191 & $\begin{array}{l}2.964 \\
(89.2)\end{array}$ & $\begin{array}{l}.412 \\
{[5]}\end{array}$ \\
\hline Punctuality of schedule & $\begin{array}{c}6.909 \\
(1.426) \\
\end{array}$ & $\begin{array}{c}7.857 \\
(1.173) \\
\end{array}$ & $.351 *$ & 3.8333 & $\begin{array}{l}2.942 \\
(87.9) \\
\end{array}$ & $\begin{array}{l}.420 \\
{[4]}\end{array}$ \\
\hline Warehouse operation & $\begin{array}{c}6.547 \\
(1.576) \\
\end{array}$ & $\begin{array}{c}7.609 \\
(1.294) \\
\end{array}$ & $.12 *$ & 3.7123 & $\begin{array}{l}2.700 \\
(86.0)\end{array}$ & $\begin{array}{l}.297 \\
{[21.5]}\end{array}$ \\
\hline Convenience of Consolidation service & $\begin{array}{c}5.719 \\
(2.818)\end{array}$ & $\begin{array}{c}7.571 \\
(1.304)\end{array}$ & .008 & irr. & irr. & n.a. \\
\hline Convenience of booking procedure & $\begin{array}{c}7.157 \\
(1.205) \\
\end{array}$ & $\begin{array}{c}7.304 \\
(1.726) \\
\end{array}$ & $.388 *$ & 3.5635 & $\begin{array}{l}2.834 \\
(98.0)\end{array}$ & $\begin{array}{l}.438 \\
{[2]}\end{array}$ \\
\hline $\begin{array}{l}\text { Convenience of cargo pick-up and } \\
\text { delivery }\end{array}$ & $\begin{array}{c}7.004 \\
(1.380) \\
\end{array}$ & $\begin{array}{c}7.723 \\
(1.237) \\
\end{array}$ & $.172 *$ & 3.7679 & $\begin{array}{l}2.932 \\
(90.7)\end{array}$ & $\begin{array}{l}.280 \\
{[25]}\end{array}$ \\
\hline Intermodal service & $\begin{array}{c}5.628 \\
(2.631) \\
\end{array}$ & $\begin{array}{c}7.633 \\
(1.356) \\
\end{array}$ & .028 & irr. & irr. & n.a. \\
\hline Free time of delivery and redelivery & $\begin{array}{c}6.795 \\
(1.592) \\
\end{array}$ & $\begin{array}{c}7.080 \\
(1.648) \\
\end{array}$ & $.194 *$ & 3.4542 & $\begin{array}{l}2.608 \\
(96.0) \\
\end{array}$ & $\begin{array}{l}.312 \\
{[18.5]}\end{array}$ \\
\hline Prompt settlement of cargo claim & $\begin{array}{c}5.052 \\
(1.748) \\
\end{array}$ & $\begin{array}{c}7.414 \\
(1.650) \\
\end{array}$ & $.042 * *$ & 3.6171 & $\begin{array}{l}2.030 \\
(68.1)\end{array}$ & $\begin{array}{l}.440 \\
{[1]}\end{array}$ \\
\hline Convenience of business location & $\begin{array}{c}6.452 \\
(1.160)\end{array}$ & $\begin{array}{l}7.257 \\
(1.603)\end{array}$ & $.276^{*}$ & 3.5406 & $\begin{array}{l}2.538 \\
(88.9)\end{array}$ & $\begin{array}{l}.395 \\
{[6]}\end{array}$ \\
\hline
\end{tabular}


Table 1. (Continued)

\begin{tabular}{|c|c|c|c|c|c|c|}
\hline Attributes & $\begin{array}{c}\text { Performance, } \\
\{1\}\end{array}$ & $\begin{array}{c}\text { Importance, } \\
\{2\}\end{array}$ & $\begin{array}{c}\text { Marginal } \\
\text { impact, } \\
\Delta R^{2}\end{array}$ & $\begin{array}{c}\text { Relative } \\
\text { importance, } \\
\gamma_{j} \\
\end{array}$ & $\begin{array}{c}\text { Weighted } \\
\text { Performance, } \\
\gamma_{j}^{*}\{1\} / 9\end{array}$ & $\begin{array}{c}\text { Distance } \\
\text { Coefficient }\end{array}$ \\
\hline Flexible pricing & $\begin{array}{c}6.109 \\
(1.864) \\
\end{array}$ & $\begin{array}{l}7.690 \\
(1.435) \\
\end{array}$ & $.192 *$ & 3.7518 & $\begin{array}{l}2.547 \\
(79.4)\end{array}$ & $\begin{array}{l}.374 \\
{[7]}\end{array}$ \\
\hline Low record of damage and loss & $\begin{array}{l}5.990 \\
2.304) \\
\end{array}$ & $\begin{array}{l}7.561 \\
1.527) \\
\end{array}$ & .015 & irr. & irr. & n.a. \\
\hline EDI capability & $\begin{array}{c}6.204 \\
(1.522) \\
\end{array}$ & $\begin{array}{c}7.214 \\
(1.773) \\
\end{array}$ & $.055^{* *}$ & 3.5196 & $\begin{array}{l}2.426 \\
(86.0) \\
\end{array}$ & $\begin{array}{l}.315 \\
{[17]} \\
\end{array}$ \\
\hline Cargo tracing ability & $\begin{array}{c}6.947 \\
(1.274) \\
\end{array}$ & $\begin{array}{c}7.614 \\
(1.393) \\
\end{array}$ & $.223 *$ & 3.7147 & $\begin{array}{l}2.867 \\
(91.2) \\
\end{array}$ & $\begin{array}{l}.319 \\
{[13]}\end{array}$ \\
\hline Accuracy in documentation & $\begin{array}{c}6.909 \\
(1.469)\end{array}$ & $\begin{array}{c}7.690 \\
(1.364)\end{array}$ & $.215^{*}$ & 3.7518 & $\begin{array}{c}2.88 \\
(89.8)\end{array}$ & $\begin{array}{l}.316 \\
{[15]}\end{array}$ \\
\hline Reliability of advertised schedules & $\begin{array}{c}6.423 \\
(1.612) \\
\end{array}$ & $\begin{array}{c}6.847 \\
(1.789) \\
\end{array}$ & $.135^{*}$ & 3.3405 & $\begin{array}{l}2.384 \\
(93.8) \\
\end{array}$ & $\begin{array}{l}.316 \\
{[15]}\end{array}$ \\
\hline Equipment in good condition & $\begin{array}{c}7.671 \\
(1.239) \\
\end{array}$ & $\begin{array}{c}7.471 \\
(1.441) \\
\end{array}$ & $.109 *$ & 3.645 & $\begin{array}{l}2.702 \\
(89.3) \\
\end{array}$ & $\begin{array}{l}.280 \\
{[25]} \\
\end{array}$ \\
\hline Availability of container & $\begin{array}{r}7.133 \\
(1.406) \\
\end{array}$ & $\begin{array}{r}7.400 \\
(1.468) \\
\end{array}$ & $.189 *$ & 3.6103 & $\begin{array}{l}2.861 \\
(96.4) \\
\end{array}$ & $\begin{array}{l}.280 \\
{[25]}\end{array}$ \\
\hline Containers in good condition & $\begin{array}{c}6.966 \\
(1.325) \\
\end{array}$ & $\begin{array}{c}7.685 \\
(1.321) \\
\end{array}$ & $.196^{*}$ & 3.749 & $\begin{array}{l}2.902 \\
(90.6) \\
\end{array}$ & $\begin{array}{l}.299 \\
{[20]}\end{array}$ \\
\hline Special equipment availability & $\begin{array}{c}6.595 \\
(1.665)\end{array}$ & $\begin{array}{c}7.719 \\
(1.283)\end{array}$ & $.045 * *$ & 3.766 & $\begin{array}{l}2.760 \\
(85.4)\end{array}$ & $\begin{array}{l}.270 \\
{[27]}\end{array}$ \\
\hline Ship with good capacity & $\begin{array}{c}6.733 \\
(1.333) \\
\end{array}$ & $\begin{array}{c}7.471 \\
(1.589) \\
\end{array}$ & $.15 *$ & 3.645 & $\begin{array}{l}2.726 \\
(90.1) \\
\end{array}$ & $\begin{array}{l}.293 \\
{[23]}\end{array}$ \\
\hline $\begin{array}{l}\text { Sum of importance scores of relevant } \\
\text { indicators }\end{array}$ & & 204.96 & & $100(\%)$ & $75.67(\%)$ & \\
\hline
\end{tabular}

Note: $*$ p-value $<0.01 ; * *$ p-value $<0.05 .{ }^{1}$ Irr. $=$ irrelevant. ${ }^{2}$ (in column 6 ) The value in the parenthesis of this column is the ratio $\{1\} /\{2\}$ of the attribute. ${ }^{3}$ (in column 7) The value in the square bracket of this column is the improvement priority. ${ }^{4}$ This attribute is insignificant at level of $5 \% .{ }^{5}$ n.a. $=$ not available.

Table 2. Correlations among latent variables with AVE in diagonal and composite reliability.

\begin{tabular}{|c|c|c|c|c|}
\hline & $\begin{array}{l}\text { Overall Service } \\
\text { Quality }\end{array}$ & Service value & Satisfaction & $\begin{array}{l}\text { Customer Behavior } \\
\text { Intentions }\end{array}$ \\
\hline Overall Service Quality & 0.676 & & & \\
\hline Service value & 0.664 & $1.000 *$ & & \\
\hline Satisfaction & 0.746 & 0.769 & 0.917 & \\
\hline Customer Behavior Intentions & 0.686 & 0.707 & 0.815 & 0.878 \\
\hline Composite reliability & 0.954 & $1.000 *$ & 0.971 & 0.956 \\
\hline Cronbach alpha & 0.945 & n.a.** & 0.955 & 0.930 \\
\hline
\end{tabular}

Note: $* 1.000$ points out the fact that only one measured variable in the $\mathrm{SV} ; * *$ n.a. $=$ not available.

with AVE in diagonals. The discriminant validity of these latent variables is verified because all AVE measures are greater than the squares of correlations. The last two rows of Table 2 provide the measures of composite reliability and Cronbach alpha of the four latent variables. The reliability of OSQ, SAT and $\mathrm{CBI}$ is also verified because all composite reliability measures exceed 0.95 and all values of Cronbach alphas exceed 0.9 . The composite reliability of SV is equal to 1.00 because only one measured variable is contained in it; henceforth, its
Cronbach alpha is not available. In summary, all statistics in Fig. 3 and Table 2 indicate that the model is fitted well.

\section{Selecting Relevant Attributes}

The selection of relevant attributes to the service performance is conducted one by one hierarchically. Two consecutive steps are involved in the analysis. First, the PLS process is applied to the model with the five control variables contained in the service effort and control variables. Second, except five 


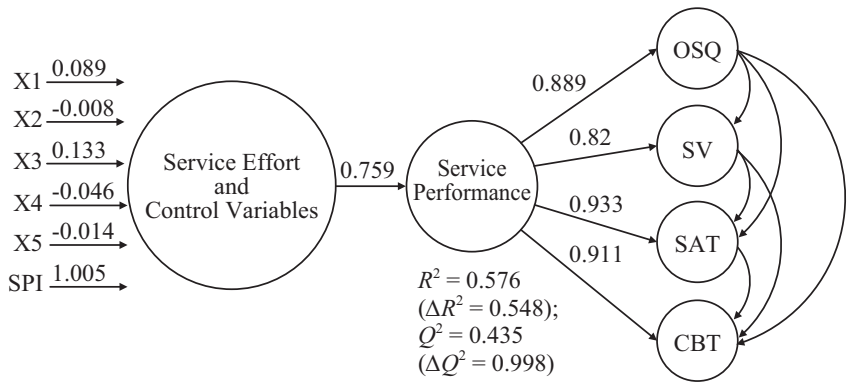

Fig. 5. Model validity of service performance index.

control variables, an attribute is added to "service effort and control variable", and the incremental $R^{2}\left(\Delta R^{2}\right)$ of latent variable "service performance" which includes all variables and their relationships used to measure the service performance of the studied company is evaluated (see Fig. 5). A statistically significant $\Delta R^{2}$ in the second step indicates that the attribute is relevant to the performance delivered by the studied company and $\Delta R^{2}$ would be interpreted as the marginal impact of this attribute on the latent variable "service performance". Then, the attribute would be remained in the index; otherwise, it would be deleted from the index. The fourth column of Table 1 shows the marginal impacts $\Delta R^{2}$ of all attributes obtained from the hierarchical analysis. In the process of hierarchical analysis, as shown in Table 1, all attributes of the sacrifice are examined to be irrelevant; another three attributers of service quality (including convenience of consolidation service, intermodal service, and low record of damage and loss) are also found to be irrelevant. Finally, 27 attributes are selected to construct the SPI for the company shown in Table 1.

The relative importance of each relevant attribute (expressed in percentage) is calculated and shown in the fifth column of Table 1. The sum of relative importance of all relevant attributes is $100 \%$, which is the maximum value of the SPI and can be interpreted as the desire service of the customers [9]. The weighted performance of each relevant attribute is shown in the sixth column of Table 1. In our case, the value of the company's SPI is $75.67 \%$, which is the sum of the weighted performance of each relevant indicator shown at the end of the sixth column of Table 1. This figure indicates that the level of service performance perceived by the customers of this company is about $75 \%$ of the customers' desire [9]. The two worst ratios of performance to importance of attributes are "Prompt settlement of cargo claim" and "Flexible pricing", whose relative performances are $68.1 \%$ and $79.4 \%$, respectively.

\section{Index Validity}

According to Diamantopoulos and Winklhofer [24], the external validity of an index should be further assessed by examining how the index relates to another variables. Thus, the correlation coefficients of SPI and the latent variables of OSQ, SV, SAT and CBI are calculated, and they were $0.73,0.623$, 0.693 and 0.674 , respectively. These values are great enough to verify the external validity of the index. The SPI was fur-

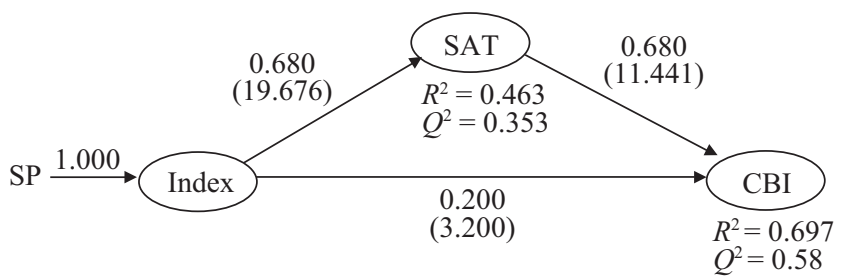

Note: the values in parentheses are the t-values estimated by boostrapping method.

Fig. 6. The reduced structural model with SPI.

ther assessed using the PLS approach with $\Delta R^{2}$ and $\Delta Q^{2}$. Note that all OSQ, SV, SAT and CBI and their relationships are included in Fig. 5. The path coefficients between OSQ, SV, SAT and CBI which are almost identical to the values in Fig. 4 are not shown in the figure for the sake of simple presentation. The results shown in Fig. 5 indicate that the model fits the data well because $\Delta R^{2}$ of the SPI was 0.548 , which is much larger than those $\Delta R^{2}$ derived from every single attribute shown in Table 1.

Note that $Q^{2}$, which was used for measuring the predictive power of a PLS model [17], showed a great increase from -0.563 to 0.435 and having $\Delta Q^{2}$ was 0.998 . In addition, the path estimates between the SPI and "service effort and control variables" is 1.005 , which is much larger than its residual. Finally, the loading between the service effort and control variables and latent variable "service" was 0.759 ; and the loadings between "service" and OSQ, SV, SAT, and CBI were $0.889,0.828,0.933$, and 0.911 , respectively. The magnitudes of those loadings are all much larger than those of their residuals. All these evidences strongly supported the validity of the developed SPI. It is also found that the five control variables and latent variables OSQ and SV are insignificantly when the index is included in the model. The reduced model after deleting OSQ and SV is shown in Fig. 6 which implies that for the purpose of predicting CBI, the SPI could take the places of OSQ and SV. This result indicates the validity of the SPI again.

\section{Ranking Improvement Priorities}

The values in the square brackets in the last column of Table 1 are the improvement priorities of the 27 relevant attributes. Ties in the attributes are handled by averaging the priorities that would have been assigned to the tied attributes and assigning this average to each of them. According to the priorities, one can find that the attributes should be improved in the first six priorities are: prompt settlement of cargo claim, convenience of booking procedure, communication/interaction with customers, punctuality of schedule, on-time cargo loading, and convenience of business location.

\section{Managerial Implications}

Figure 7 is the scatter plot of pairs $\left(1-\frac{x_{j}}{M}, \Delta R_{j}^{2}\right)$ of the 27 


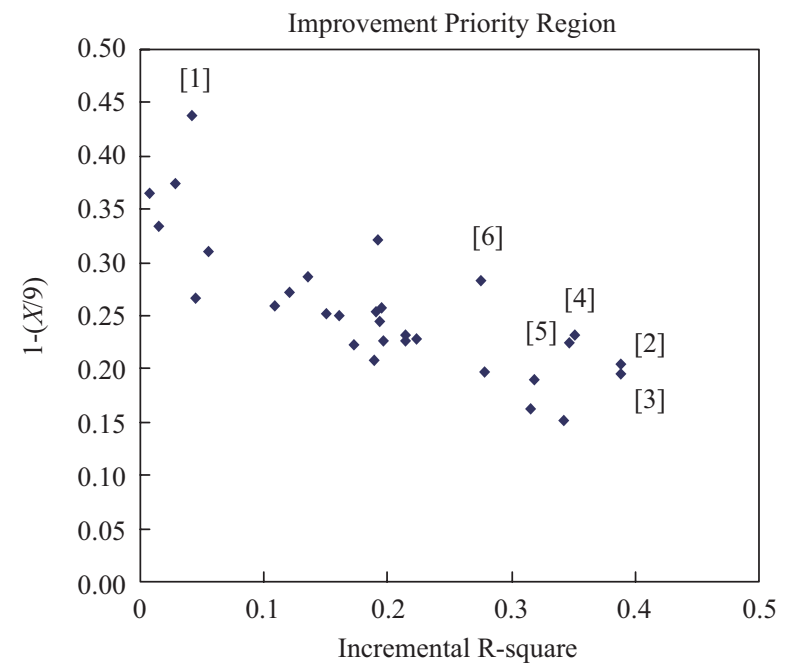

Note: the square brackets are the improvement priorities of the points near them.

Fig. 7. The scatter plot of pairs $\left(1-\frac{x_{j}}{M}, \Delta R_{j}^{2}\right)$.

service attributes. The values in square brackets are the improvement priorities of the points near them. From the information displayed in Fig. 7 and Table 1, some valuable cues for service improvement to the studied company are discovered and discussed as follows:

(1) The six points corresponding to the attributes within the first six improvement priorities (as pointed out in section 4.7) are the farthest points from the origin, as shown in Fig. 7. Five of these six attributes belong to the construct of operation ability of the studied company; this implies that the operation ability of the company perceived by the customers should be considered to improve in the first priority.

(2) The first 11 improvement priorities of attributes (as shown in Table 1) are fallen into two constructs: operation ability and employee's ability. The fact that 11 attributes that are perceived by the customers as the lowest scores of SIS concentrate in these two constructs implies that the service performance provided by the employees at the front line need to be raised for improving the service performance of the company. A training program for enhancing their concepts and technologies on customer relationship management may be a suitable scheme to be adopted by the company.

(3) The attributes ranked in the least three priorities belong to the construct of equipment supply ability. This fact implies that the equipment of the company has well enough and there is no need to place huge investment on purchasing equipment in the near future.

\section{CONCLUSIONS}

\section{Discussion}

Under the four assumptions, the SPI is devised in a way that the attributes included in SPI are determined by a service performance model which is built according to the knowledge of marketing theories and the relative importance of the relevant attributes determined by the data directly surveyed from respondents. A service improvement score (SIS) is also devised for ranking the improvement priorities for the attributes included in SPI. For illustrating the proposed approach, the service performance improvement of an international container shipping company is studied. On the basis of the belief that both direct and indirect sources will contain some but not all valuable information to the service performance, this paper emphasizes on the utilization of information as broad as possible. The PLS analysis is employed for model examination and attribute selection. Development of SPI and SIS makes the implementation of service performance improvement easier than the previous methods in two aspects: (1) SPI provides a numerical descriptive measure for the service performance rather than a visual judgment on an IP matrix, and (2) SIS can assess the improvement priorities for each attributes explicitly which is also a property that Abalo et al. (2007) pursued.

The hierarchical PLS procedure gives the managers an opportunity to grasp at all relevant attributes for managerial control propose. Comparing the previous studies conducted by Arnett et al. [5] and Helm [40], they only included a small numbers of attributes or factors in their indexes. For example, the RE index developed by [5] comprised only five out of 18 factors to avoid the high correlation between indicators. The current study attempts to include more service attributes into SPI which would provide a practical tool for the managerial application because managers would hardly concentrate on a few attributes and ignore some deleted attributes with great importance scores when they monitor the performance of their services delivered to the customers.

On the contrary, instead of using service quality (SQ) or satisfaction (SAT) as the performance in IPA, the service performance model of this paper includes overall service quality (OSQ), service value (SV), satisfaction (SAT) and customer behavior intentions (CBI) to allow the service performance model excluding some importance attributes perceived by customers but irrelevant to the firm's service performance. For example, the ocean freight rate which is undoubtedly an important factor recognized by customers of the container shipping industry and its importance score is 7.98 ranking the second highest score among those 36 attributes; but it is excluded in the SPI due to its relative small standard deviation (1.326). The current proposed method provides the researchers and managers an alternative approach to analyze service quality instead of choosing methods from the extant literatures. The authors believe the proposed approach will provide further insights for the study of IPA.

\section{Limitation and Future Research}

Although this research is conducted in the context of a 
single company, the proposed method could benefit from additional tests using other marketing setting or other shipping companies or industries. Studies using the SPI and SIS to investigate complex issues would provide further validation of the indexes. For example, linking SPI and SIS to other marketing variables such as actual repurchase behavior, or comparing SPI and SIS of competitors are possible directions for the future study. In addition, an alternative way to develope SIS is by giving weights to the relative importance and the marginal impact of the coefficients of indicators in SIS; that might reflect more of the service characteristics for a specific company. Besides, although the $R^{2}$ and $Q^{2}$ of both SPI and SAT were significant for CBI, a lot of exploratory power and predictive relevance gaps exist between SPI, SAT and CBI; that also requires further improvement.

\section{ACKNOWLEDGMENTS}

This work was supported by the National Science Council of Taiwan under grant NSC 97-2410-H-019 -017.

\section{REFERENCES}

1. Abalo, J., Varela, J., and Manzano, V., "Importance values for importanceperformance analysis: A formula for spreading out derived from preference rankings," Journal of Business Research, Vol. 60, No. 2, pp. 115-121 (2007).

2. Ajzen, I., "From intentions to actions: A theory of planned behavior," in: Kuhl, J. and Bechmann, J. (Eds.), Action Control: From Cognition to Behavior, Springer, Heidelberg, Germany, pp. 11-39 (1985).

3. Anderson, E. W. and Fornell, C., "Foundations of the American customer satisfaction index," Total Quality Management, Vol. 11, No. 7, pp. 869882 (2000)

4. Andrew, F. M., "Construct validity and error components of survey measures: A structural modeling approach," Public Opinion Quarterly, Vol. 48, pp. 409-442 (1984).

5. Arnett, D. B., Laverie, D. A., and Meiers, A., "Developing parsimonious retailer equity indexes using partial least squares analysis: A method and applications," Journal of Retailing, Vol. 79, pp. 161-170 (2003).

6. Athanassopoulos, A. D., "Customer satisfaction cues to support market segmentation and explain switching behavior," Journal of Business Research, Vol. 47, pp. 191-207 (2000).

7. Babakus, E., Ferguson, C. E., and Boller, G. W., "An empirical assessment of the SERVQUAL scale," Journal of Business Research, Vol. 24 pp. 253-268 (1992).

8. Bacon, D. R., "A comparison of approaches to importance-performance analysis," International Journal of Market Research, Vol. 45, No. 1, pp. 55-71 (2003).

9. Berry, L. L., Parasuraman, A., and Zeithaml, V. A., "Ten lessons for improving service quality (Report No. 93-104),” Marketing Science Institute (1993).

10. Bollen, K., Structure Equations with Latent Variables, New York: John Wiley \& Sons (1989).

11. Bollen, K. and Lennox, R., "Conventional wisdom on measurement: A structural equation perspective," Psychological Bulletin, Vol. 110, No. 2, pp. 305-314 (1991).

12. Bolton, R. N. and Drew, J. H., “A multistage model of customers' assessments of service quality and value," Journal of Consumer Research, Vol. 17, No. 4, pp. 875-884 (1991).

13. Brooks, M. R., Determinants of Shipper's Choice of Container Carrier: A Study of Eastern Canadian Exporters, Unpublished Doctoral Dissertation,
Department of Maritime Studies and International Transport, University of Wales, College of Cardiff, UK (1983).

14. Brown, T. J., Churchill, G. A. Jr., and Peter, P. J., "Improving the measurement of service quality," Journal of Retailing, Vol. 69, No. 1, pp. 127-139 (1993).

15. Carman, J. M., "Consumer perceptions of service quality: An assessment of the SERVQUAL dimensions," Journal of Retailing, Vol. 66, No. 1, pp. 33-55 (1990).

16. Cassel, C. M., Hackl, P., and Westlund, A. H., "On measurement of intangible assets: A study of robustness of partial least squares," Total Quality Management, Vol. 11, No. 7, pp. 897-907 (2000).

17. Chin, W. W., "The partial least squares approach to structural equation modeling," in: Marcoulides, G. A. (Ed.), Modern Methods for Business Research, Lawrence, Mahwah, NJ, pp. 295-336 (1998).

18. Crompton, J. L. and Duray, N. A., "An investigation of the relative efficacy of four alternative approaches to importance-performance analysis," Journal of Academic and Marketing Science, Vol. 13, No. 4, pp. 69-80 (1985).

19. Cronin, J. J., Jr., Brady, M. K., and Hult, G. T. M., "Assessing the effects of quality, value, and customer satisfaction on consumer behavioral intentions in service environments," Journal of Retailing, Vol. 76, No. 2, pp. 193-218 (2000).

20. Cronin, J. J., Jr. and Taylor, S. A., "Measuring service quality: A reexamination and extension," Journal of Marketing, Vol. 56, No. 3, pp. 55-68 (1992).

21. Cronin, J. J., Jr. and Taylor, S. A., "SERVPERF versus SERVQUAL: Reconciling performance based and perceptions-minus-expectations measurement of service quality," Journal of Marketing, Vol. 58, No. 1, pp. 125-131 (1994).

22. Danaher, P. J., "Using conjoint analysis to determine the relative importance of service attributes measured in customer satisfaction surveys," Journal of Retailing, Vol. 73, No. 2, pp. 235-260 (1997).

23. Deng, W. J., "Fuzzy importance-performance analysis for determining critical service attributes," International Journal of Service Industry Management, Vol. 19, No. 2, pp. 252-270 (2008).

24. Diamantopoulos, A. and Winklhofer, H. M., "Index construction with formative indicators: An alternative to scale development," Journal of Marketing Research, Vol. 38, No. 2, pp. 269-277 (2001).

25. Dodds, W. B., Monroe, K. B., and Dhruv, G., "Effects of price, brand, and store information on buyers' product evaluations," Journal of Marketing Research, Vol. 28, pp. 307-319 (1991).

26. Dolinskv, A. L. and Caputo, R. K., "Adding a competitive dimension to importance-performance analysis: An application to traditional health care systems," Health Care Marketing Quarterly, Vol. 8, No. 3, pp. 61-79 (1991).

27. Ennew, C. T., Reed, G. V., and Binks, M. R., "Importance-performance analysis and the measurement of service quality," European Journal of Marketing, Vol. 27, No. 2, pp. 59-70 (1993).

28. Fishbein, M. and Ajzen, I., Belief, Attitude, Intention and Behavior, Addison-Wesley, Reading, M. A. (1975).

29. Fornell. C., "A national customer satisfaction barometer: The Swedish experience," Journal of Marketing, Vol. 56, pp. 6-21 (1992).

30. Fornell, C., Johnson, M. D., Anderson, E. W., Jaesung, C., and Bryant, B. E., "The American customer satisfaction index: Nature, purpose, and findings," Journal of Marketing, Vol. 60, pp. 7-18 (1996).

31. Fornell, C. and Larcker, D., "Evaluating structural equation models with unobservable variables and measurement error," Journal of Marketing Research, Vol. 18, pp. 39-50 (1981).

32. Fu, J.-R., VisualPLS - Partial Least Square (PLS) Regression - An Enhanced GUI for Lvpls (PLS 1.8 PC) Version 1.04, from National Kaohsiung University of Applied Sciences, Taiwan, ROC. Web site: http: //www2.kuas.edu.tw/prof/fred/vpls/index.html (2006).

33. Geisser, S., "The predictive sample re-use method with applications," Journal of the American Statistical Association, Vol. 70, pp. 320-328 (1975).

34. George, J. M., "Extrinsic and intrinsic origins of perceived social loafing 
in organizations," Academy of Management Journal, Vol. 35, No. 1, pp. 191-202 (1992).

35. Green, P. E. and Rao, V. R., "Conjoint measurement for quantifying judgment data," Journal of Marketing Research, Vol. 8, pp. 355-363 (1977).

36. Gronroos, C., "A service quality model and its 12 marketing implications," European Journal of Marketing, Vol. 18, No. 4, pp. 36-44 (1984).

37. Gupta, S. and Zeithaml, V. A., "Customer metrics and their impact on financial performance," Marketing Science, Vol. 25, No. 6, pp. 718-739 (2006).

38. Hallowell, R., "The relationship of customer satisfaction, customer loyalty, and profitability: An empirical study," The International Journal of Service Industry Management, Vol. 7, No. 4, pp. 27-42 (1996).

39. Heeler, R. M., Okechuku, C., and Reid, S., "Attribute importance: Contrasting measurements," Journal of Marketing Research, Vol. 16, No. 1, pp. 60-63 (1979)

40. Helm, S., "Designing a formative measure for corporate reputation," Corporate Reputation Review, Vol. 8, No. 2, pp. 95-109 (2005).

41. Jaccard, J., Brinberg, D., and Ackerman, L. J., "Assessing attribute importance: A comparison of six methods," Journal of Consumer Research, Vol. 12, pp. 463-468 (1986).

42. Jacoby, J., Knox, R., and Brinberg, D., "Prediction of behavior from beliefs: An extension and test of a subjective probability model," Journal of Personality and Social Psychology, Vol. 37, pp. 1239-1248 (1979).

43. Jarvis, C. B., MacKenzie, S. B., and Podsakoff, P. M., "A critical review of construct indicators and measurement model misspecification in marketing and consumer research," Journal of Consumer Research, Vol. 30, No. 2, pp. 199-218 (2003).

44. Lages, L. F. and Fernandes, J. C., "The SERPVAL scale: A multi-item instrument for measuring service personal values," Journal of Business Research, Vol. 58, No. 11, pp. 1562-1572 (2005)

45. Lin, C. H., Sher, P. J., and Shih, H. Y., "Past progress and future directions in conceptualizing customer-perceived value," International Journal of Service Industry Management, Vol. 16, No. 4, pp. 318-336 (2005).

46. Lu, C. S., "The impact of carriers service attributes on the shipper-carrier partnering relationships: a shipper's perceptive," Transportation Research Part E: Logistics and Transportation Review, Vol. 39, No. 5, pp. 399-415 (2003).

47. Martilla, J. A. and James, J. C., "Importance-performance analysis," Journal of Marketing, Vol. 41, No. 1, pp. 77-79 (1977).

48. Matzler, K., Bailom, F., Hinterhuber, H. H., Renzl, B., and Pichler, J., "The asymmetric relationship between attribute-level performance and overall customer satisfaction: A reconsideration of importance-performance analysis," Industrial Marketing Management, Vol. 33, No. 4, pp. 271-277 (2004).

49. Matzler, K., Sauerwein, E., and Heischmidt, K. A., "Importanceperformance analysis revisited: The role of the factor structure of customer satisfaction," Service Industries Journal, Vol. 23, No. 2, pp. 112-130 (2003).

50. McColl-Kennedy, J. and Schneider, U., "Measuring customer satisfaction: Why, what and how," Total Quality Management, Vol. 11, No. 7, pp. 883896 (2000)

51. Meyer, A., Das Deutsche Kundenhummder, München, Germany: LudwigMaimilians-Universitat München (1994).

52. Mittal, V., Ross, W. T., and Baldasare, P. M., "The asymmetric impact of negative and positive attribute-level performance on overall satisfaction and repurchase intentions," Journal of Marketing, Vol. 62, pp. 33-47 (1998).

53. Neslin, S. A., "Linking product features to perceptions: Self-stated versus statistically revealed importance weights," Journal of Marketing Research, Vol. 18, pp. 80-86 (1981).

54. O'Leary, J. T. and Adams, M. B., Community Views Concerning Urban Forest Recreation Resources, Facilities and Services' US Forest Service, North Central Forest Experiment Station, Chicago, Illinois (1982).

55. Oliver, R. L., Satisfaction: A Behavioral Perspective on the Consumer,
NY: McGraw-Hill (1997).

56. Olshavsky, R. W., "Perceived quality in consumer decision making: An integrated theoretical perspective," in: Jacoby, J. and Olson, J. (Eds.), Perceived Quality: How Consumers View Stores and Merchandise, Lexington Books, Lexington, MA, pp. 3-30 (1985).

57. Parasuraman, A., Berry, L. L., and Zeithaml, V., "Refinement and reassessment of the SERVQUAL scale," Journal of Retailing, Vol. 67, No. 4, pp. 420-450 (1991).

58. Parasuraman, A. and Grewal, D., "The impact of technology on the qualityvalue-loyalty chain: A research agenda," Journal of the Academy of Marketing Science, Vol. 28, No. 1, pp. 168-74 (2000).

59. Parasuraman, A., Zeithaml, V. A., and Berry, L. L., "A conceptual model of service quality and its implications for future research," Journal of Marketing, Vol. 49, No. 4, pp. 41-50 (1985).

60. Parasuraman, A., Zeithaml, V. A., and Berry, L. L., "SERVQUAL: A multiple item scale for measuring consumer perception of service quality," Journal of Retailing, Vol. 64, No. 1, pp. 12-37 (1988).

61. Parasuraman, A., Zeithaml, V. A., and Berry, L. L., "Reassessment of expectations as a comparison standard in measuring service quality: Implications for future research," Journal of Marketing, Vol. 58, pp. 111-124 (1994).

62. Peter, J. P., Churchill, G. A., Jr., and Brown, T. J., "Caution in the use of difference scores in consumer research," Journal of Consumer Research, Vol. 19, pp. 655-662 (1993).

63. Petrick, J. F., "Development of a multiple dimensional scale for measuring the perceived value of a service," Journal of Leisure Research, Vol. 34 No. 2, pp. 119-134 (2002).

64. Rust, R. T. and Chung, T. S., "Marketing models of service and relationships," Marketing Science, Vol. 25, No. 6, pp. 560-580 (2006).

65. Sambonmatsu, D. N., Kardes, F. R., Houghton, D. C., and Ho, E. A., "Overestimating the importance of the given estimation in multiattribute consumer judgment," Journal of consumer psychology, Vol. 13, No. 3, pp. 289-300 (2003)

66. Sampson, S. E. and Showalter, M. J., "The importance-performance response function: Observations and implications," Service Industries 13 Journal, Vol. 19, No. 3, pp. 1-26 (1999).

67. Stokes, R. C., "The effect of price, package design and brand familiarity on perceived quality," in: Jacoby, J. and Olson, J. (Eds), Perceived Quality: How Consumers View Stores and Merchandise, Lexington Books, Lexington, MA, pp. 233-246 (1985)

68. Stone, M., "Cross-validatory choice and assessment of statistical predictions," Journal of the Royal Statistical Society, Series B, Vol. 36, No. 2, pp. 111-133 (1974)

69. Taylor, S. A., "Assessing regression-based importance weights for quality perceptions and satisfaction judgments in the presence of high order and/ or interaction effects," Journal of Retailing, Vol. 73, No. 1, pp. 135-159 (1997).

70. Teas, K. R., "Expectations, performance evaluation, and consumers' perceptions of quality," Journal of Marketing, Vol. 57, pp. 18-34 (1993).

71. Werts, C. E., Linn, R. L., and Joreskog, K. G., "Intraclass reliability estimates: Testing structural assumptions," Educational and Psychological Measurements, Vol. 34, pp. 25-33 (1974).

72. Yavas, U. and Habib, G., "Correlates of franchisee satisfaction: The case of Saudi car dealers," International Journal of Physical Distribution \& Material management, Vol. 17, No. 3, pp. 46- 55 (1987).

73. Zeithaml, V. A., "Consumer perceptions of price, quality, and value: A means-end model and synthesis of evidence," Journal of Marketing, Vol. 52, pp. 2-22 (1988, July).

74. Zeithaml, V. A., Berry, L. L., and Parasuraman, A., "The behavioral consequences of service quality," Journal of Marketing, Vol. 60, pp. 31-46 (1996).

75. Zeithaml, V. A., Rust, R. T., and Lemon, K., "Make customer profitability the basis for service," Working Paper, University of North Carolina, Chapel Hill, NC (1999). 